\title{
Variability in ectohydrolytic enzyme activities of pelagic marine bacteria and its significance for substrate processing in the sea
}

\author{
Josefina Martinez ${ }^{1,2, *}$, David C. Smith ${ }^{1}$, Grieg F. Steward ${ }^{1}$, Farooq Azam ${ }^{1}$ \\ ${ }^{1}$ Marine Biology Research Division, Scripps Institution of Oceanography, University of California, San Diego, \\ La Jolla, California 92093-0202, USA \\ ${ }^{2}$ Department of Microbiology, University of Barcelona, Avda. Diagonal 645, E-08028 Barcelona, Spain
}

\begin{abstract}
Microbial utilization of polymeric and particulate organic matter in aquatic environments depends on the activities of hydrolytic ectoenzymes present in the periplasm or bound to bacterial surfaces. Numerous studies have quantified this activity and shown that it is an ubiquitous phenotype of bacterial populations in oceans and lakes. However, little is known about the distribution of this activity among the different species that constitute the bacterial community in natural assemblages. We examined whether marine bacteria isolated from several types of particles and from the surrounding seawater exhibit different patterns of hydrolytic enzyme activities. We screened 44 marine isolates for the presence of enzymatic activity measured as the hydrolysis of fluorogenic substrates. Isolates were obtained from Southern California Bight (USA) seawater after size fractionation to concentrate unattached or particle-attached bacteria. Isolates were also obtained from larvacean houses and aggregates produced in laboratory microcosms which had been enriched with nutrients to create phytoplankton blooms. The activities of the following enzymes were assayed: protease, $\beta$-glucosidase, $\alpha$-glucosidase, alkaline phosphatase, lipase and chitinase. Cell-specific activities of all enzymes varied over a broad range (4 to $3810 \mathrm{amol} \mathrm{cell-1} \mathrm{h}^{-1}$ for protease; 0 to 35 amol cell $\mathrm{a} \mathrm{h}^{-1}$ for $\beta$-glucosidase; 0 to 8 amol cell $\mathrm{l}^{-1}$ $\mathrm{h}^{-1}$ for $\alpha$-glucosidase; 0.7 to $410 \mathrm{amol} \mathrm{cell-1} \mathrm{h}^{-1}$ for alkaline phosphatase; 0.2 to $584 \mathrm{amol} \mathrm{cell}^{-1} \mathrm{~h}^{-1}$ for lipase; 0 to $559 \mathrm{amol}$ cell ${ }^{-1} \mathrm{~h}^{-1}$ for chitinase) suggesting shifts in the dominant species of bacteria could strongly influence the rates and patterns of polymer and particle hydrolysis in seawater. Some isolates had a single dominant activity, which varied among isolates. This suggests 'specialization' for different types of polymeric substrates in different species. However, no distinct differences in enzyme activity profiles were found between isolates collected from various types of particles versus those from the surrounding water.
\end{abstract}

KEY WORDS: Ectoenzyme - Marine bacteria - Organic matter decomposition

\section{INTRODUCTION}

Hydrolytic ectoenzymes present in the periplasm and cell envelope of marine bacteria are of fundamental importance for the processing of polymeric and particulate organic matter in the sea. Numerous studies have shown that this activity is a common feature of marine bacterial populations (Hollibaugh \& Azam

•E-mail: jose@opg1.ucsd.edu
1983, Hoppe 1983, Somville \& Billen 1983, Ammerman \& Azam 1985). In addition, recent studies have shown that bacteria inhabiting marine snow have cell-specific ectoenzymatic activities up to 3 orders of magnitude higher than bacteria in the surrounding water (Karner \& Herndl 1992, Smith et al. 1992). DeLong et al. (1993) found bacteria belonging to the Cytophaga/Flavobacteria group (a group known to degrade a wide range of polymeric compounds) to be more abundant on marine snow than in the surrounding water and suggested this may explain the presence of high hydrolytic enzyme 
activities previously observed on marine snow (Smith et al. 1992). While the present information is limited, it does raise the question of the variability in the types and intensity of hydrolytic ectoenzyme activity among different bacterial species in natural assemblages and the consequences of such variability for the hydrolysis of polymers and particles in the sea.

Numerous studies using direct in situ measurements of bacterial ectoenzymatic activity have been done since highly sensitive methods using fluorogenic substrates became available (Pettersson \& Jansson 1978 , Hoppe 1983, Somville \& Billen 1983). Some of the field studies showed fluctuation in the expression of ectoenzymatic activities in oceans and lakes which can be ascribed to seasonal and trophic status changes of the ecosystem (Chróst et al. 1986, Rath et al. 1993). We could expect these changes to result from regulation of enzyme induction and expression as well as species selection and population dynamics. Hybridization of total community DNA with oligonucleotide probes based on 16S rRNA sequence data has shown that single species of culturable bacteria can rise as dominant components of the pelagic bacterial assemblages (Rehnstam et al. 1993). In such situations the enzymatic profile (i.e. the types and levels of enzyme activity) of the dominant species would determine the pattern of the hydrolysis of polymers and particles in the environment.

In this study we tested whether there is significant variability in the enzyme profiles of different bacterial assemblages and isolates. We examined the activities of 6 different hydrolytic ectoenzymes (protease, $\alpha$-glucosidase, $\beta$-glucosidase, alkaline phosphatase, lipase and chitinase) in 44 pelagic bacterial strains which we isolated either from seawater or from particles. Enzymes were assayed in isolates under defined growth conditions, and the data were used to address specific hypotheses. Although differences in growth conditions may affect the expression of the enzymes, this was not studied here. Further, we examined timevariability of enzyme profiles at the assemblage level in seawater samples collected periodically off the Scripps Institution of Oceanography (California, USA) pier. The time-variations of enzyme profiles at the assemblage level were also examined in seawater samples in 91 microcosms which had been enriched with inorganic nutrients to create phytoplankton blooms.

\section{MATERIALS AND METHODS}

Bacterial isolation from seawater. Seawater samples were collected $\sim 1 \mathrm{~km}$ offshore of the Scripps pier $\left(32^{\circ} 51^{\prime} \mathrm{N}, 117^{\circ} 15^{\prime} \mathrm{W}\right)$. On 2 occasions, 14 l seawater was gravity filtered through $10 \mu \mathrm{m}$ Nitex netting and the retained particles were rinsed 4 times with sterile seawater, removed from the filter by resuspending in $10 \mathrm{ml}$ sterile seawater and centrifuged at $500 \mathrm{rpm}$ $(53 \times g)$. Individual particles were rinsed 4 times with $5 \mathrm{ml}$ sterile seawater. Particles were then spread on agar plates $(1.5 \% \mathrm{wt} / \mathrm{vol}$ agar, Difco) made with ZoBell $2216 \mathrm{E}$ medium $(5 \mathrm{~g}$ peptone, $1 \mathrm{~g}$ yeast extract in $1 \mathrm{l}$ of $0.45 \mu \mathrm{m}$ Millipore-filtered seawater, autoclaved at $121^{\circ} \mathrm{C}$ for $\left.30 \mathrm{~min}\right)$. Free-living bacteria from the same water were isolated by plating $0.1 \mathrm{ml}$ of $1 \mu \mathrm{m}$ filtered seawater. After incubation at $17^{\circ} \mathrm{C}$ for 2 to $7 \mathrm{~d}$, isolates were chosen on the basis of colony morphology to increase the chance of picking different species. The strains were divided into 2 series, designated SA (seawater; attached to particles) and SF (seawater; free-living).

Bacterial isolation from microcosms. Phytoplankton blooms were created in 91 carboys of $150 \mu \mathrm{m}$ filtered seawater collected from the Scripps pier and enriched with inorganic nutrients $\left(\mathrm{NaNO}_{3}, 10 \mu \mathrm{M}\right.$ final conc.; $\mathrm{NaH}_{2} \mathrm{PO}_{4}, 2 \mu \mathrm{M}$ final conc.; $\mathrm{NaSiO}_{3}, 10 \mu \mathrm{M}$ final conc.; vitamins and trace metals). The carboys were incubated at $16^{\circ} \mathrm{C}$ and were exposed to continuous light at $0.2 \times 10^{16}$ quanta s${ }^{-1} \mathrm{~cm}^{-2}$. In 2 separate experiments, aggregates produced after the bloom were collected, rinsed, and bacteria were isolated from them as above. On one occasion, bacteria were isolated from abandoned larvacean houses in the carboys. To isolate nonattached bacteria in the bottles, samples were allowed to sediment for $30 \mathrm{~min}$, and plates were inoculated with $1.0 \mu \mathrm{m}$ filtrates of the supernatant. Colonies were chosen as above and this series of strains was designated BA (isolates attached to aggregates produced after the phytoplankton bloom); BF (isolates from the bulk water); LA (isolates from larvacean houses) and LF (isolates from the bulk water of the microcosm with larvacean houses).

Ectoenzyme activities. Ectoenzyme activities were assayed using fluorogenic substrates (Hoppe 1983, Hoppe et al. 1988) derived from 7-amino-4-methylcoumarin (AMC) and 4-methyl-umbelliferone (MUF). Protease activity was assayed as the hydrolysis rate of leucine-AMC. $\alpha$-D-glucosidase and $\beta$-D-glucosidase activities were assayed as the hydrolysis rates of MUF$\alpha$-D-glucoside and MUF- $\beta$-D-glucoside, respectively. MUF-oleate was used to assay lipase activity. We found this substrate dissolves optimally in ethylene glycol monomethyl ether at $20^{\circ} \mathrm{C}$. Alkaline phosphatase was assayed using MUF-phosphate. Chitinase activity was assayed using MUF- $N$-acetyl- $\beta$-D-glucosamine. Enzyme activities measured by means of fluorogenic substrates were expressed in terms of the rate of MUF or AMC production. The substrates, dissolved in ethylene glycol monomethyl ether, were added to 
the samples at $20 \mu \mathrm{M}$ final concentration for natural assemblages and at 50 to $100 \mu \mathrm{M}$ final concentration for bacterial isolates. All samples were run in duplicate or triplicate with $0.2 \mu \mathrm{m}$ filtered and boiled seawater serving as controls. Standard solutions of MUF and AMC were used to calibrate the fluorometer.

Cultures: Enzyme activities were assayed on exponential phase cultures grown in ZoBell medium at $17^{\circ} \mathrm{C}$ after the cells were harvested by centrifugation $(3200 \times g)$ and resuspended in $0.2 \mu \mathrm{m}$ filtered sterile seawater. The assays were done at cell densities of $10^{6}$ to $10^{7} \mathrm{ml}^{-1}$.

Seawater: Four seawater samples were collected from the Scripps pier from 10 to 16 November 1993. Enzyme activities were assayed within $1 \mathrm{~h}$ of sampling.

Aggregates: Aggregates on which to assay the enzyme activities were obtained as follows: $20.5 \mathrm{ml}$ samples were withdrawn from carboys in which a phytoplankton bloom had been created (see above). They were placed in baked scintillation vials and rolled for $1 \mathrm{~h}$ at $3 \mathrm{rpm}$ to induce aggregation (Shanks \& Edmondson 1989). After rolling, the vials were stood on end and the aggregates allowed to settle. It should be noted that some free-living bacteria may have been included in the aggregates during the process of rolling. Hydrolytic ectoenzyme activities (protease, $\beta$ glucosidase and alkaline phosphatase) were followed for $95 \mathrm{~h}$ following aggregation. Enzyme assays were performed on $100 \mathrm{\mu l}$ aliquots of the aggregate enriched slurry and $1.25 \mathrm{ml}$ of the surrounding water.

Enumeration of bacteria. Bacteria counts were performed by epifluorescence microscopy after staining the cells with 4',6-diamidino-2-phenyl indole (DAPI; Porter \& Feig 1980). Prior to filtration, Tween-80 (Sigma) was added (10 $\mu \mathrm{M} \mathrm{ml}^{-1}$, final conc.) and the samples were sonicated for $30 \mathrm{~s}$ in order to dissociate bacteria from the aggregates (Yoon \& Rosson 1990).

\section{RESULTS}

\section{Enzyme profiles of isolates}

All our 44 isolates expressed protease, alkaline phosphatase and lipase while the majority of the isolates also expressed chitinase $(90 \%), \alpha$-glucosidase $(68 \%)$ and $\beta$-glucosidase $(80 \%)$ (Table 1$)$. However, the cellspecific activities of each enzyme in different isolates varied over 3 orders of magnitude (Table 1). Further, the enzyme profiles of different isolates were quite variable (Fig. 1). The 'enzyme profile' of an isolate is defined here as the cell-specific activities of all 6 enzymes for a given isolate. As such, it can be used to compare different isolates in terms of their cell-specific activities of individual enzymes and whether this relationship is different for different enzymes. Such comparison of enzyme profiles (Fig. 1) shows that: (1) as mentioned, individual enzyme activities varied greatly between isolates; (2) isolates expressing high activity of 1 or 2 enzymes expressed low relative activities of the other enzymes (for example, BF-7, a highly proteolytic strain, had undetectable $\alpha$-glucosidase, $\beta$-glucosidase and chitinase and low alkaline phosphatase and lipase activities); (3) none of the isolates had high relative activities of all enzymes, i.e. there were no 'super-bugs' among our isolates.

\section{Enzyme profiles of the natural assemblages}

Seawater samples. The cell-specific activities of individual enzymes as well as the assemblage enzyme profiles showed high variability among the 4 samplings over a period of $7 \mathrm{~d}$ (Fig. 2). The cell-specific protease, phosphatase and lipase activities were high on all days. Interestingly, their levels were within the range of the values for the 44 isolates, and their peak values during the 4 sampling days were comparable to the mean values for the respective enzymes for the 44 isolates. $\alpha$ - and $\beta$-glucosidase were undectable ( 3 samples) or barely detectable (1 sample). Chitinase activity was not detectable in any sample. The individual enzyme activities as well as the enzyme profiles varied significantly. Protease, phosphatase and lipase all varied $\sim 4$-fold during the sampling days but the variations of the individual enzymes were generally not in the same direction, resulting in substantial variations in the relative activities of various enzymes in the assemblage. Thus, even though bacterial abundance remained fairly constant during the 4 sampling days, the changes in assemblage enzyme profile suggest that enzyme activities of bacteria on the polymeric and par- 


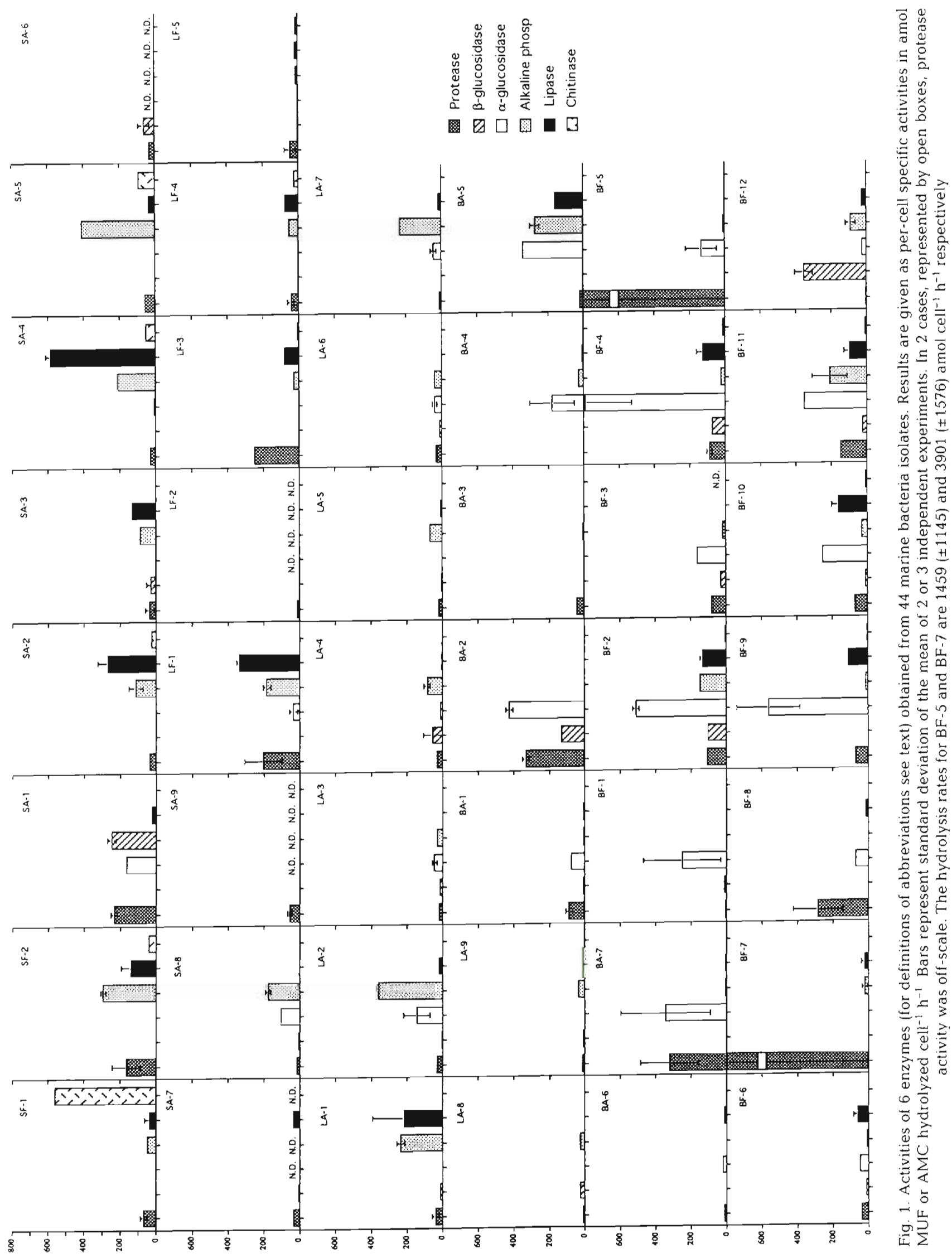




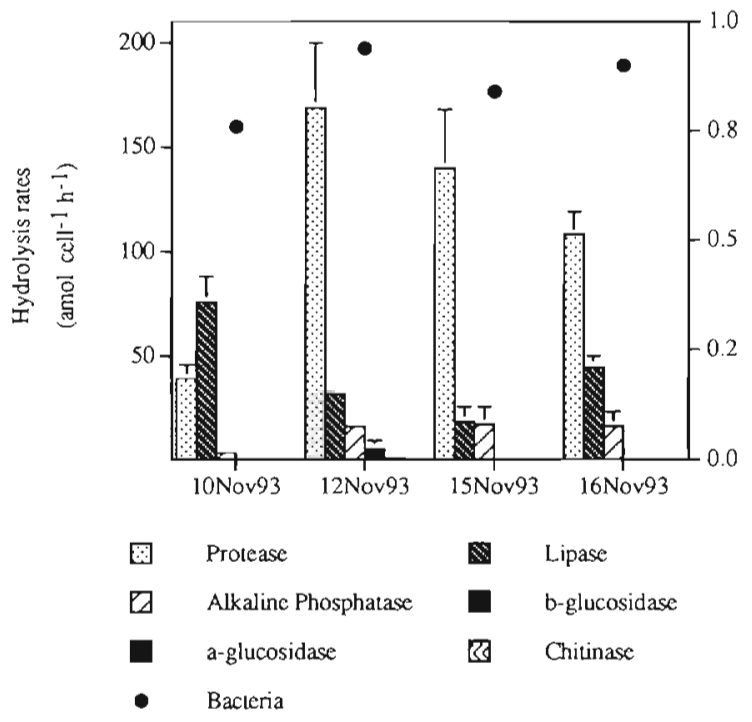

Fig. 2. Cell-specific enzyme activities and bacterial abundance in 4 samples of seawater from the Scripps Institution of Oceanography (California, USA) pier. Bars represent standard deviation of the mean of duplicates

ticulate phases in seawater would be substantially different. This is seen more dramatically in the microcosm experiment (see below).

Microcosm study. We measured protease, $\beta$-glucosidase and alkaline phosphatase activities in phytoplankton aggregates and the surrounding water periodically for $95 \mathrm{~h}$ (however, we cannot be sure whether, or to what degree, there was an exchange between the bacteria on the aggregates and those in the surrounding water). The cell-specific enzyme activities in the aggregates were generally an order of magnitude higher than in the surrounding water (Fig. 3). The protease activity in the surrounding water ranged from 250 to $2700 \mathrm{amol} \mathrm{cell}{ }^{-1} \mathrm{~h}^{-1}$ and that for the aggregates ranged from 1700 to $24000 \mathrm{amol} \mathrm{cell}{ }^{-1} \mathrm{~h}^{-1}$. The protease and glucosidase in the aggregates and surrounding water were also much higher than in the seawater samples discussed (above) and, interestingly, these levels were also generally much higher than those for the 44 isolates (Table 1). Thus, the highest hydrolysis rate for protease activity among the isolates $(3810 \mathrm{amol}$ AMC cell ${ }^{-1} \mathrm{~h}^{-1}$ ) is still almost 1 order of magnitude lower than the maximum rate found for the aggregates. The range of variation of individual enzyme activities over the sampling period was $\sim 3$-fold in the surrounding water; in the aggregates, the range was also $\sim 3$-fold for alkaline phosphatase but it was higher for glucosidase (6-fold) and protease ( 10 -fold). The relative activities of the 3 enzymes varied significantly in the aggregates as well as in the surrounding water (Fig. 3).
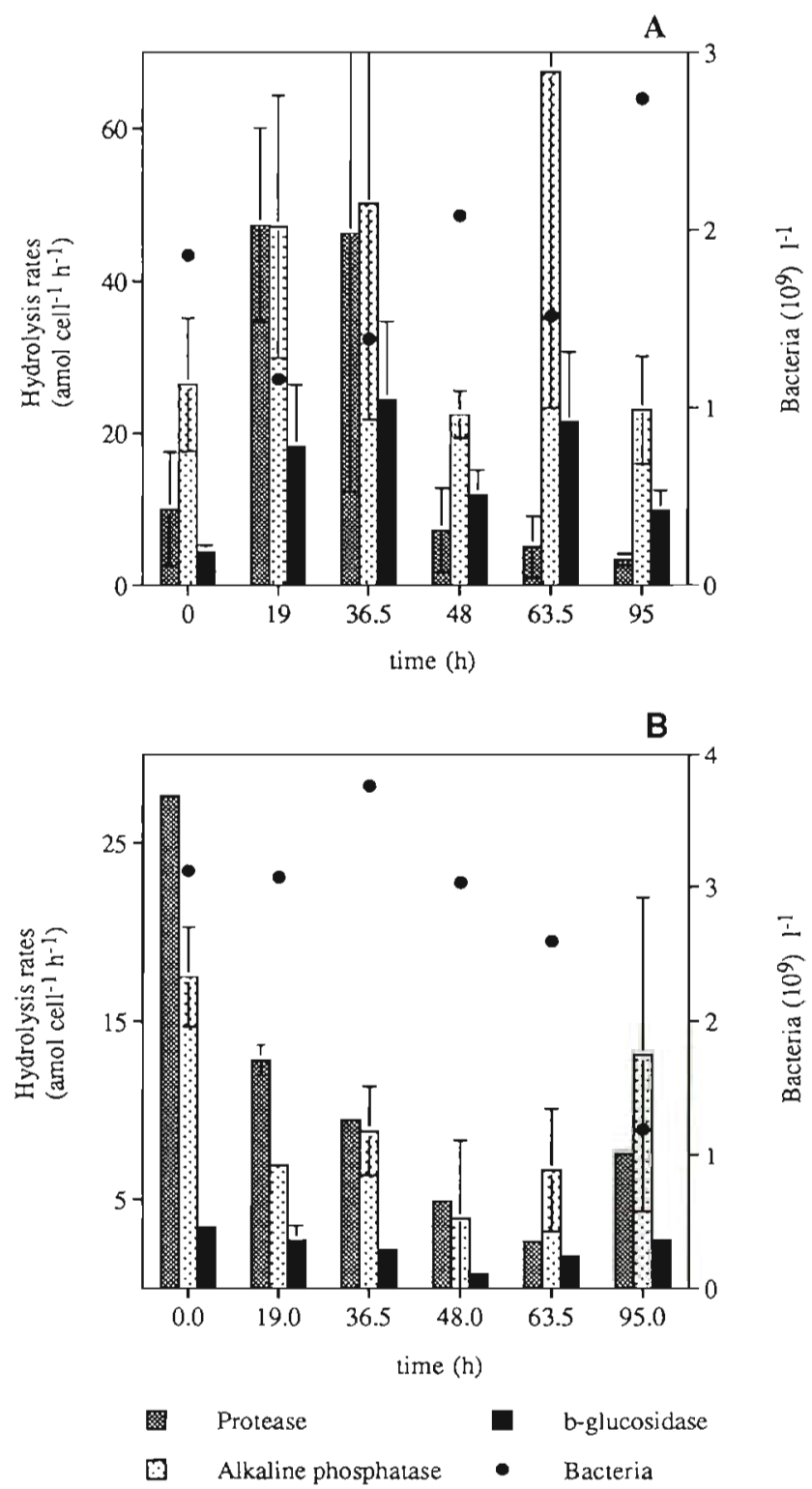

Fig. 3. Cell-specific enzyme activities and bacterial abundance in (A) phytoplankton aggregates and (B) the surrounding water after a phytoplankton bloom created in mesocosms Values of protease activity were divided by 500 for aggregates and 100 for the surrounding water. Bars represent standard deviation of the mean of duplicates

\section{DISCUSSION}

Bacteria in the pelagic ocean experience, and their ectohydrolases act upon, a continuum of organic matter which includes 'hot spots' of concentrated organic matter such as living and dead phytoplankton and marine snow (Azam \& Ammerman 1984, Alldredge \& Silver 1988, Biddanda \& Pomeroy 1988, Azam et al. 1993) as well as lower concentrations of organic matter 
in the intervening zones. In the bacterium's microenvironment the concentrations of ectohydrolase substrates, dissolved polymers, colloids and suspended particles can therefore vary spatially and temporally over a broad range. One might thus expect ectohydrolase profiles of pelagic bacteria to reflect strategies to optimize nutrient acquisition from polymers and particles distributed patchily in space and in time. Further, the species-specific ectohydrolase profiles might reflect optimization strategies within multi-species assemblages.

Our field measurements (Fig. 2) show that substantial day-to-day changes in the assemblage's individual enzyme activities and enzyme profiles can occur at a single location. Further, the ectohydrolase profiles for the aggregate-associated and free-living bacteria in the laboratory microcosm showed large variations in a time-frame of less than $1 \mathrm{~d}$ (Fig. 3). These results are consistent with recent studies (Karner et al. 1992, Rath et al. 1993) which found variation in ectohydrolase profiles along a trophic gradient and explained it as reflecting the environment's trophic status. Such variations have implications for the rates and the nature of organic matter processing in the sea. They could be caused by shifts in species dominance or in the level of enzyme expression by the same species in response to changes in the organic matter field. The finding that aggregate-associated bacteria expressed much higher cell-specific activities relative to free-living bacteria (Fig. 3) could likewise be due to either of these causes. These results agree with a recent work by Smith et al. (1995) showing that, during a phytoplankton bloom created in a mesocosm, cell-specific hydrolysis rates of ectoenzymes were dominated by the attached bacteria. It is also relevant here that DeLong et al. (1993) found marine aggregates to harbor bacteria which were phylogenetically distinct from those in the surrounding water and belonged to the highly hydrolytic Cytophaga group. We do not know whether this was the case in our experiment, since we did not perform phylogenetic analysis of attached and free-living bacteria. The enzyme profiles of our isolates, which were derived from particles and surrounding water, may provide some insights.

In culture, as in nature, the enzyme profiles reflect the bacterium's genotypic identity as well as phenotypic response to environmental conditions. Our isolates were grown in the same medium, so they all experienced the same high peptide concentrations. Yet, they expressed cell-specific protease activities which ranged over 3 orders of magnitude ( 4 to 3810 amol cell ${ }^{-1} \mathrm{~h}^{-1} ;$ Fig. 1). If these results can be extrapolated to protein-rich microzones, e.g. aggregates, autolysing algae or dead zooplankton, then our isolates might be expected to exert vastly different proteolytic activity to hydrolyse the protein in their environment. What magnitude, and microenvironmental variation, of cell-specific protease activity is actually expressed in seawater under different conditions (e.g non-bloom, bloom and aggregates) might be inferred from measurement of field and microcosm samples (Figs. $2 \& 3$ ). The cell-specific protease activities of the field samples and of bacteria in the water surrounding the aggregates were in the range found for the isolates; the specific activity range of the isolates covers the range of these samples. Bacteria associated with aggregates expressed higher protease activities, at times even an order of magnitude higher than the most proteolytic isolate. If we take at face value the comparison between cultures and the 3 types of assemblages (field, surrounding water and aggregates) we would conclude that the average bacterium in seawater expresses as high or higher protease than bacteria cultured under conditions where at least some isolates would have been expected to express high levels of protease. The activities of the other 5 ectoenzymes also showed similar behavior to that of protease (Fig. 1).

As seen in Figs. 1-3, not only the individual enzyme activities but also the enzyme profiles of isolates and assemblages varied significantly. The enzyme profiles and their variations have implications for the rates and the nature of organic matter processing in the sea. Smith et al. (1992) proposed the idea of 'enzymatic fractionation' of carbon, nitrogen and phosphorus on sinking marine aggregates due to differences in the relative activities of protease, phosphatase and glucosidase of attached bacteria. Our observations of bacterial enzyme profiles are consistent with, and extend, this idea. All our isolates showed distinctly different enzyme profiles under identical growth conditions (Fig. 1). If these 44 enzyme profiles are assumed to represent the range encountered in the sea then the enzymatic processing of organic matter could dramatically change due to shifts in species dominances. Shifts in enzyme profiles do occur on aggregates and in surrounding water (as documented in this study and other studies including Smith et al. 1992) but these could be due to species shift or a change in the response of the same population. One could speculate that bacterial consortia with different but complementary ectohydrolase profiles could act on organic particles to rapidly solubilize various major macromolecular components. On the other hand, dominance of a single species on an aggregate could generate an enzyme profile which would enhance the selectivity of solubilization of specific macromolecular components.

Among our isolates there was no significant difference ( $t$-test; $p>0.05$ ) between the group mean hydrol$y$ sis rates of particle-attached and free-living bacteria 
for any of the enzymes studied. Our measurements on aggregates in this study and earlier studies lead to the consistent pattern that aggregate-associated bacteria have extremely high protease activity. Whether this is the hallmark of aggregate bacteria cannot yet be tested for lack of a sufficiently broad database. However, we note that only 2 of our isolates (BF-5 and BF-7) had specific protease activity comparable to our aggregate samples. It is possible that the expression of enzyme profiles characteristic of particle specialists requires environmental conditions not present in our cultures, e.g. attachment to particles.

Lipase activity was prominent among the ectohydrolytic enzymes assayed in this study; cell-specific lipase was present at substantial levels in all isolates and in all seawater assemblage samples. It was the dominant activity in one seawater sample (Fig. 2; November 10 sample) and in 10 of our 44 isolates. It thus appears that ectolipase is an important bacterial phenotype in the sea. Its significance in organic matter cycling in the ocean and lakes has received attention only recently (Boon 1989, 1990, Gajewski et al. 1993, Rath et al. 1993). Hoppe (1986) found 'some' lipase activity in the 0.2 to $1 \mu \mathrm{m}$ size fraction of seawater. Lipids might occur in seawater as cell membranes of dead organisms and from a variety of other biological sources. Protozoa surfaces may be a source of substrate for bacterial lipases. Killing of marine phytoplankton by direct attack of marine gliding bacteria has been reported (Imai et al. 1991, 1993). These authors suggest that gliding bacteria can potentially regulate and/or reduce primary productivity by their algicidal activity when they colonize macroaggregates. Gliding bacteria are known to have high hydrolytic activity and, although these authors did not suggest it, attack and hydrolysis of cytoplasmic membrane could provide a mechanism by which bacteria kill marine phytoplankton. Another source of substrate for bacteria lipases can be lipid released from protozoa (Nagata \& Kirchman 1992).

$\alpha$ - and $\beta$-glucosidase presented 'low' values of activity for all the isolates in comparison with the other enzymes tested (Fig. 1). Results for natural bacterial assemblages often indicate low activity for $\alpha$ - and $\beta$-glucosidase. This is surprising in view of the high concentrations of polysaccharide in seawater (Benner et al. 1992). We cannot rule out the possibility that the fluorogenic substrates used for measuring $\alpha$ - and $\beta$-glucosidase activities are inappropriate (and that the enzyme activities are actually much higher than is recognized).

While alkaline phosphatase has been reported to be produced mainly by phytoplankton (Chróst \& Overbeck 1987), we found significant alkaline phosphatase activity for all the isolates tested. Chróst (1990) sug- gests bacteria can produce alkaline phosphatase to supply their metabolism with organic carbon substrates, which are also final products of phosphoester hydrolysis. Preliminary studies in our lab suggested that the substrate MUF-P is hydrolysed to some extent by nucleotidase as well as by alkaline phosphatase. In any case the high phosphatase activity found in our isolates suggest an important role of bacteria in phosphorus flux in some microenvironments

In summary, we have presented here evidence of the variability of ectoenzyme profiles among 44 marine bacterial isolates. Differences over time and space in field and mesocosm studies in this work and others may thus reflect changes in the composition of the bacterial population. Thus the species composition of the bacterial community could substantially influence the rates and patterns of polymer and particle hydrolysis in the sea and consequently influence organic matter processing and $\mathrm{C}, \mathrm{N}$ and $\mathrm{P}$ fluxes in the ocean.

Acknowledgements. We thank Richard A. Long for valuable collaboration in maintaining the marine isolates. This work was supported by an NSF grant to F.A.

\section{LITERATURE CITED}

Alldredge A.L, Silver M (1988) Characteristics, dynamics and significance of marine snow. Prog Oceanogr 20:41-82

Ammerman JW, Azam F (1985) Bacterial 5'-nucleotidase in aquatic ecosystems: a novel mechanism of phosphorus regeneration. Science 227:1338-1340

Azam F, Ammerman JW (1984) Cycling of organic matter by bacterioplankton in pelagic marine ecosystems: microenvironmental considerations. In: Fasham MJR (ed) Flows of energy and materials in marine ecosystems. Plenum Publishing. New York, p 345-360

Azam F, Martínez J, Smith DC (1993) Bacteria-organic matter coupling on marine aggregates. In: Guerrero R, PedrósAlió C (eds) Trends in microbial ecology. Spanish Society for Microbiology, Barcelona, p 410-414

Benner R, Pakulski JD, McCarthy M, Hedges JI, Hatcher PG (1992) Bulk chemical characteristics of dissolved organic matter in the ocean. Science 255:1561-1564

Biddanda BA, Pomeroy LR (1988) Microbial aggregation and degradation of phytoplankton-derived detritus in seawater. I. Microbial succession. Mar Ecol Prog Ser 42: $79-88$

Boon PJ (1989) Organic matter degradation and nutrient regeneration in Australian freshwaters: I. Methods for exoenzyme assays in turbid aquatic environments. Arch Hydrobiol 115:339-359

Boon PJ (1990) Organic matter degradation and nutrient regeneration in Australian freshwaters: II. Spatial and temporal variation, and relation with environmental conditions. Arch Hydrobiol 117:405-436

Chróst RJ (1990) Microbial ectoenzymes in aquatic environments. In: Overbeck J, Chróst RJ (eds) Aquatic microbial ecology: biochemical and molecular approaches. Brock/ Springer, New York, p 47-78

Chróst RJ, Overbeck J (1987) Kinetics of alkaline phosphatase activity and phosphorus availability for phytoplankton 
and bacterioplankton in Lake Plußsee (North German eutrophic lake). Microb Ecol 13:229-248

Chróst RJ, Wcislo R, Halemejko GZ (1986) Enzymatic decomposition of organic matter by bacteria in a eutrophic lake. Arch Hydrobiol 107:145-165

DeLong EF, Franks DG, Alldredge AL (1993) Phylogenetic diversity of aggregate-attached vs free-living marine bacterial assemblages. Limnol Oceanogr 38:924-934

Gajewski AJ, Chróst RJ, Siuda W (1993) Bacterial lipolytic activity in an eutrophic lake. Arch Hydrobiol 128:107-126

Hollibaugh JT, Azam F (1983) Microbial degradation of dissolved proteins in seawater. Limnol Oceanogr 28: 1104-1116

Hoppe HG (1983) Significance of exoenzymatic activities in the ecology of brackish water: measurements by means of methylumbelliferyl-substrates. Mar Ecol Prog Ser 11. 299-308

Hoppe HG (1986) Relations between bacterial extracellular enzyme activities and heterotrophic substrate uptake in a brackish water environment. Deuxième Colloque International de Bactériologie marine. Actes de colloque, Brest, $119-128$

Hoppe HG, Kim SJ, Gocke K (1988) Microbial decomposition in aquatic environments: combined process of extracellular enzyme activity and substrate uptake. Appl Environ Microbiol 54:784-790

Imai I, Ishida Y, Hata Y (1993) Killing of marine phytoplankton by a gliding bacterium Cytophaga sp., isolated from the coastal sea of Japan. Mar Biol 116:527-532

Imai I, Ishida Y, Sawayama S, Hata Y (1991) Isolation of a marine gliding bacterium that kills Chattonella antiqua (Raphidophyceae). Nippon Suisan Gakk 57:1409

Karner M, Fuks D, Herndl GJ (1992) Bacterial activity along a trophic gradient. Microb Ecol 24:243-257

Responsible Subject Editor: J. T. Hollibaugh, Tiburon, California, USA
Karner M. Herndl G (1992) Extracellular enzymatic activity and secondary production in free-living and marinesnow-associated bacteria. Mar Biol 113:341-347

Nagata T, Kirchman DL (1992) Release of macromolecular organic complexes by heterotrophic marine flagellates. Mar Ecol Prog Ser 83:233-240

Pettersson K, Jansson M (1978) Determination of phosphatase activity in Jake water-a study of methods. Verh Int Ver Limnol 20:1226-1230

Porter KG, Feig YS (1980) The use of DAPI for identifying and counting aquatic microflora. Limnol Oceanogr 25:943-948

Rath J, Schiller C, Herndl GJ (1993) Ectoenzymatic activity and bacterial dynamics along a trophic gradienty in the Caribbean Sea. Mar Ecol Prog Ser 102:89-96

Rehnstam AS, Bäckman S, Smith DC, Azam F, Hagström $\AA$ (1993) Blooms of sequence-specific culturable bacteria in the sea. FEMS Microb Ecol 102:161-166

Shanks AL, Edmondson EW (1989) Laboratory-made artificial marine snow: a biological model of the real thing. Mar Biol 101:463-470

Smith DC, Simon M, Alldredge AL, Azam F (1992) Intense hydrolytic enzyme activity on marine aggregates and implications for rapid particle dissolution. Nature 359:139-142

Smith DC, Steward GF, Long RA, Azam F (1995) Bacterial mediation of carbon fluxes during a diatom bloom in a mesocosm. Deep Sea Res II 42:75-97

Somville M, Billen G (1983) A method for determining exoproteolytic activity in natural waters. Limnol Oceanogr 28: $190-193$

Yoon WB, Rosson RA (1990) Improved method of enumeration of attached bacteria for study of fluctuation in the abundance of attached and free-living bacteria in response to diel variation in seawater turbidity. Appl Environ Microbiol 56:595-600

Manuscript first received: December 11, 1995

Revised version accepted: March 16, 1996 